\title{
THE COLUMBIA STUDY OF COMPENSATION FOR AUTOMOBILE ACCIDENTS: AN UNANSWERED CHALLENGE
}

FLÈMING JAMES, JR.*

In 1932 Dean Smith wrote for this Review: "The' Report by the Committee to Study Compensation for Automobile Accidents is among the significant documents which have appeared in recent years." $\mathrm{He}$ referred to a report to the Columbia University Committee for Research in the Social Sciences which was made on the basis of a survey of the economic consequences of automobile accidents. ${ }^{2}$ The Columbia Study included an investigation of thousands of actual cases, which represented a fair sample of experience, both urban and rural, across the nation. ${ }^{3}$ It seems to me that this survey is probably the most significant contribution to the study of torts to appear so far in the twentieth century. ${ }^{4}$

Another landmark study of the economic consequences of accidental injury, the Railroad Study, made by the Railroad Retirement Board, covered work injuries in the railroad industry for the years 1938-1940.5

These careful and comprehensive case studies both dealt with the way accident losses were actually being met under a common law system of liability and with the consequences of uncompensated losses in terms of human hardship to the injured persons, their families, and others indirectly affected. Both studies contained grave indictments of the present system. These may be summarized as follows :

(1) Despite a few very high awards, the common law system by and large did not fully compensate accident victims even for their actual economic loss. This inadequacy was especially pronounced where the loss was greatest, in serious and fatal injury cases. ${ }^{6}$

* Lafayette S. Foster Professor of Law, Yale University.

1. Smith, The Problem and Its Solution, in Compensation for Automobile Accidents: A Symposinm, 32 Colum. L. REv. 785 (1932).

2. Committee to Study Compensation for Automobile Accrdents, Report to the Columbia University Council For Research in the Social Sciences (1932) [hereinafter cited as CoLUMBria STUdY].

3. Id. at $8-13,255-82$.

4. The only real rivals, in my opinion, are the earlier studies which led to workmen's compensation legislation. A brief reference to them may be found in 1 LARson, Workmen's Compensation Law $\$ 5.20$ (1952). See also MrLlis \& Montgomery, Labor's Risks and Social Insurance 189 (1938) ; Reisenfeld \& Maxweld, Modern Sociar Legislation 131 (1950). Perhaps the best known of these is the report of the Wainwright Commission in New York. 25 N.Y. Senate Doc. No. 38 (1910).

5. U.S. RamRoad RETIREMENT BD., WORK INJuRIES IN THE RaIlroad INDUSTTY 1938-40 (1947) [hereinafter cited as RAILROAD STUDY].

6. The Colunnbia Study showed that some payment was made in over $85 \%$ of all cases where defendant was insured. Columbia STudy 75, 77, 86, 87, 204, 262. When the amount of payment is compared with the economic loss, however, the following appears: "In the small loss groups the losses in the insured cases are more than covered by the payment received, while in the large loss groups the losses are not covered." Id. at 266. 
(2) Where defendant was financially irresponsible no significant payments were made, ${ }^{7}$ but even' where there was financial responsibility inadequacy of compensation was marked. ${ }^{8}$

(3) Where payment -was made, it 'was often 'delayed, with hardship consequent upon the delay, particularly where the loss was serious.' Where litigation was resorted to, this delay was greatly increased.9

(4) The great majority of persons injured had been in the lower income groups, ${ }^{10}$ and most payments for injuries resulted from a process 'of bargaining wherein the claimant was in the weaker bargaining position' because of his economic need and the prospects of delay:' The more serious 'the loss, the weaker his 'bargaining position.'t1

(5) There was a great disparity in 'receipt of payments among those suffering similar economic losses-a coidition of feast and famine. ${ }^{12}$

This conclusion is based upon computations of wage loss plus medical expense, up to the time of investigation only. The Committee declared that "if it were possible to compute the future loss in earning capacity and the future medical expense for these cases and relate this total loss to the payment received, ..... the-settlements. [in serious cases] would be found to be even more inadequate." Ibid.

The study showed that in permanent disability eases wherein defendants were insured, payments were nearly, twice the losses where losses were under $\$ 250$; payments were about $50 \%$ greater than losses where losses were between $\$ 250$ and $\$ 749$; losses 'exceeded payments by the ratio of about 7 to 6 where losses were between $\$ 750$ and $\$ 2,499$; losses were over twice the amount of payments where losses were between $\$ 2,500$ and $\$ 4,999$, and ncarly three times the amount 'of 'payments where' lossès exceeded $\$ 5,000$. Ibid.

The Railrodd Study showed that in cases involving a surviving widow and children, compensation for fatal injuries to men under sixty "represented a restoration on the average of about one-third of the wage loss." RAILROAD STUDY 12. For permanent total disability, payments averaged $60 \%$ of the wages the employee might have earned. Ibid. For permanent partial disabilities the net payments restored between one-fourth and 'one-half of the wage- loss. Id. at 13. Thus it will be noted that in-the employee cases the proportion of wage loss restored in cases involving non-fatal injuries was' slightly higher in cases of serious loss than in less serious cases. See also note 12. infra.

For summaries of some of the findings of the two 'studies, see. 'Corstvet, The Un compensated Accident and Its Cónsequences, 3 LAw \& CoNTEMPI ProB 466 (1936); Pollack, Workmen's Compeisation' for Railroad Work Injuries and Diseases, 36 CoRNel. L.Q. 236. (1951).

7. The Columbia Study showed that in the uninsured defendant cases some payment was made in $27 \%$ of the temporary disability cases, in $21 \%$ of such permanent disability cases, and in only $17 \%$ of such cases involving fatalities: CoLUMBDIA STUDY 75 . Payments covered economic loss up to time of settlement in only $11 \%$ of the uninsured defendant cases involving temporary, disability and in only about $5 \%$ of such cases involving serious loss. Id. at 203-04. See also id. at 261-66, -269-73.

8. See note 6 supra; note 12 , infra.

9. See Columbia Study $205,278-80$; RaIlroad Study 146-58.

10. The Columbia Study found that in the great majority of cases studied the family was supported by one or more wage earners receiving small wages, and that "most of the adults who were injured were themselves earners, three-fourths of whom earned less than $\$ 40$ a week." ColuxiriA STUDY 55 . See also id. at 66; 218-20; RAILroad' STUDY 67-68; Corstvet, stupra note 6, at 471-75.

11. See RallRodD-Siudy 47; Corstvet, sutpra note, 6, at 468; Pollack, silpra note 6, at $242-45$.

12, See Columbia Study 266-68. The Railroad Study made an even more complete tabulation of the disparity between payments and losses. See RAILROAD STUDY 13.: It contains many suggestive tables. . Id. at 101, 107, 115, 119, 129, 133. The illuminating text accompanying these tables points out that while the adjusted average wage restoration in permanent total disability cases is $60 \%$. "this average is little more than the midpoint of a wide range, which shows that in 11 cases out of 83 , payment covers less 
(6) Even those who got large payments were not able to preserve these sums so as to assure themselves against continuing economic losses from the accidents. ${ }^{13}$

The Columbia Study concluded that a system was needed which would distribute payments more promptly and more equitably according to losses, and which would provide for meeting future needs by periodic payments. It proposed a scheme of compensation for automobile accidents along the lines of workmen's compensation acts. ${ }^{14}$

In spite of the grave defects of our present system as a method of compensating accident victims, only one jurisdiction in the Anglo-American world, the province of Saskatchewan, Canada, has adopted a system of compensation in any field besides that of industrial accidents. ${ }^{15}$ The tendency among European countries has been towards strict liability in motor vehicle cases, but none of them has substituted modified scheduled losses for tort damages. ${ }^{10}$

The continued failure of this proposal to secure wider adoption prompts several inquiries. Is the need still there; or have the glaring defects been partly cured under the present system? If they have not, are there defects in the proposed system as grave as, or graver than, those we now have, so that the proposal deserves to fail on the merits? If a compensation system is desirable on the merits, how can we account for the failure? It is the purpose of this article to consider these questions.

The studies we are considering dealt with events that happened some time ago: the Columbia Study nearly three decades, the Railroad Study nearly

than a quarter of the loss, in 25 cases from one-quarter to one-half, in 28 cases from one-half to three-quarters, and in the remaining 19 cases three-quarters or more." Id. at 120. See also Pollack, supra note 6, at 248 (range in permanent total disability cases from zero to $\$ 50,000$ ).

13. See RaIlRoad Study 15, 16, 166-76; Pollack, supra note 6, at 250-51. The Columbia Study did not investigate this aspect of the problem.

14. See Columbia Study 215-17; cf. id. at 237-45. The Railroad Study does not contain an explicit recommendation of compensation legislation for railroad workers. However, one member of the Railroad Retirement Board remonstrated because "in large part, the report consists of argument, express or implied, in support of a system of worlsmen's compensation for railroad employees." RaIl ROAD STUDY 219. This member believed that the report therefore went beyond the authority conferred by the Senate resolution authorizing the Board to make the investigation and report. In reply the chairman of the Board pointed to the letter from the Senate Interstate Commerce Committee transmitting the resolution to the Board and said that in view of its language "and of the actual findings of the study which, without advocating, show the need for a workmen's compensation system in the railroad industry, it would have been perfectly proper, in my opinion, if the report had made specific recommendations for the enactment of such a system." Sec RAIlROAD STUDY 223-24.

15. Sask. Rev. Stat. ch. 371 (1953). The plan is described in Saskatchewan Gov't Insurance Office, The Automobile Accident Insurance Act (1958); Grad, Recent Developments in Automobile Accident Compensation, 50 CoLUM. L. REv. 300, 320-25 (1950). The plan was discussed in Wis. Legislative Councis, Report oN Motor VeHICLE Accidents, vol. II, pt. II, at 132-66 (1953). The Legislative Council did not recommend adoption of compensation for Wisconsin, but it did find that the scheme was a success in Saskatchewan and was accepted by a majority of citizens there as a "worthwhile venture." Id. at 161, 165-66. See also N.D. LeGISLAtive Researcil Comm., Report on Automobile Liability Insurance 26-51 (1950).

16. Malone, Damage Suits and the Contagious Principle of Workmen's Compensation, 10 NACCA L.J. 44 (1952). 
two. Much has happened since then, including war, inflation, and prosperity. Dean Smith said in 1932: "Verdicts in excess of $\$ 10,000$ were very rare, most of thein occurring in New York City . ....'17 Today we often read of verdicts which are fabulous by contrast. ${ }^{18}$ The personal injury plaintiffs' bar has become organized into an articulate association with a vigorous educational program for its members, clamoring for the ever more "adequate award."19 The application of legal rules has changed measurably so that both the requirement of fault and the strength of defendants' defenses have been diluted. ${ }^{20}$ The role of the jury has expanded. ${ }^{21}$ A greater proportion of automobiles are insured.22 There has been a great increase in hospital and medical insurance; ${ }^{23}$ and other forms of social insurance have also had an effect. ${ }^{24}$

Has the impact of all these things changed the situation fundamentally? The awards to successful litigants have certainly been increased by more than the rise in the cost of living, and much larger amounts are now paid in settlement of the dramatic, outstanding cases. But how have accident victims fared by and large? Has there been prompter and more equitable distribution of payments according to losses? Or do we still have feast and famine-jackpot justice, but with larger prizes for the winners?

17. Smith, supra note 1 , at 794.

18. The National Association of Claimants' Compensation Attorneys tabulates in its publication, NACCA Law Journal, verdicts or awards exceeding $\$ 50,000$. See, e.g., 20 NACCA L.J. 388-404 (1957), listing 53 verdicts and awards of $\$ 100,000$ or more, mostly for the period from March to November 1957. The highest award to a single plaintiff was a jury verdict in Chicago for $\$ 750,000$, "believed to be the largest award in a single case in the history of the nation." $I d$. at 398 . This case was finally settled for $\$ 600,000$. 21 NACCA L.J. 407 (1958). Of the 53 awards for $\$ 100,000$ or over, only 8 of them were made in New York State.

19. For a brief statement of the history and purposes of the National Association of Claimants' Compensation Attorneys, see Horovitz, Editorial, 10 NACCA L.J. 17 (1952); Lambert, Editorial, 18 NACCA L.J. 25 (1956).

The term "adequate award" has become particularly associated with its use by Melvin M. Belli, former president of the organization. See Belli, The Adequate Award, 39 CALIF. L. Rev. 1 (1951).

20. See, e.g., 2 HARPER \& JAMES, Torts \$\$ 12.1-.3 (1956); James, Inroads on Old Tort Concepts (pts. 1-2), 14 NACCA L.J. 226, 15 NACCA L.J. 281 (1954-1955); Malone, Damage Suits and the Contagious Principle of Workmen's Compensation (pts. 1-2), 9 NACCA L.J. 20, 10 NACCA L.J. 44 (1952).

As to railroad work injuries, the change in the legal climate is well known. The Railroad Study found that for the ycars 1938-1940 over one-half of FELA cases disposed of by judgment after contest were in favor of defendant. RAILROAD STUDY 46. By 1951, opponents of compensation for railroad workers were able to argue that "it is evident [from recent leading cases] that the F.E.L.A. does impose liability upon the employer for almost every type of railroad accident ...." Richter \& Forer, The Railroad Industry and Work-Incurred Disabilities, 36 CoRNELL L.Q. 203, 232 (1951).

21. See 2 HARPER \& JAMES, TORTS $\$ \S 15.1-.5,16.10,17.1-2,18.8$ (1956).

22. This is widely claimed to be the result of safety responsibility legislation. See, e.g., Netherton, Highway Safety Under Differing Types of Liability Legislation, 15 OHто St. L.J. 110, 121 (1954); Note, 66 HARv. L. REv. 1300, 1310 (1953).

23. See McVay, Reply to "The Case for Compulsory Automobile Conpensation Insurance," 15 Oноо ST. L.J. 161, 170 (1954) ; N.Y. Times, Sept. 8, 1958, p. 1, cols. 7, 8 ("In New York State, more than 90 per cent of the population has some form of health insurance . ...").

24 This has been particularly true in railroad work accidents. Pollack, supra note 6 , at 263 . But today even a person injured in an automobile accident may receive workmen's compensation payments, social security benefits, and, in a very few states, disability benefits. 
One of the foremost needs in the study of torts during this third quarter of our century is a comprehensive factual examination of the economic consequences of automobile accidents which will: (1) bring up to date the findings made in the Columbia Study; (2) find out what claimants have done with the large amounts paid them for injuries or death involving substantial future economic loss, and the extent to which that disposition has enabled claimants to meet future losses; and (3) determine whether periodic payments (elg., under workmen's compensation) have in fact been more effective than lismp sum payments to meet future losses. ${ }^{25}$

It is entirely possible not only that compensation is still inequitably distributed and is 'on the whole too little and too late, but also that 'even' the large awards are too often dissipated by improvidence and unwise investment so that they are less effective to meet future needs than much smaller amounts would be if paid periodically. A good deal of what we do know poirits to these conclusions. Much of what was found in the older studies can be seen to restult from hiuman nature itself or from aspects of the situation, such as calendar delay, ${ }^{26}$-which have not improved. Later studies, although not comprehensive enough, suggest that there has been no fundamental change. ${ }^{27}$ Opponents of

25. Such a study would be expensive and difficult to carry out. It should include, for instarice, a comparison of 'cases in' which lump 'sums have been paid with cases involving similar injuries in which periodic payments have been made. 'The disposition of pdyments in cach 'case' in the two groups and the effectiveriess of those payments in meeting the needs of the injured person and his family would then have to be'traced. This would call for maximum 'cooperation' from people being investigated about what they would regard as-intimate details. Their natural resistance to such inquiries would be buttressed by the fact that their most likely ladvisers on the subject ' (e.g., their lawyers and labor organizations) would probably be opposed to the making of such a study.

26. See Burger, The Courts on Trial: A Call for Action Against Delay, 44 'A.B.A.J. $738-(1958)$ !

27. A study was made of automobile accidents occurring in Philadelphia in 1953. Temple University 'Bureau of 'Economic and Business Research,' Economic-Financial Consequences' of 'Personal Injuries' Sustained in 1953 Philadelphia Auto Acciddnts, 7 ECoN. \& Bus. Butl. No. 3 (March 1955). Since this study is tot twidely available; some of its findings will be noted here: ${ }^{1}$.

Income status of earner victims, nonfatal cases : $27.6 \%$ earned less than $\$ 50$ a week, $32.6 \%$ between $\$ 51$ and $\$ 70,31.3 \%$ between $\$ 71$ and $\$ 100$. Id. at 27 .

"Personal injuries resulting from ' automobile accidents result in out-of-pocket loss, a large part' of which is never recovered" Id. at 90 . See also id. at 85 .'

'While there was 'some form of hospital insurance in about $45 \%$ of the cases studied, "the incidence of surgical coverages increases with income, and cash disability policies were reported only among the upper income groups." Id at 30 . Most of what was paid on' account of injuries came from third-party. liability insurance, id. at 85-86, 90, but uninsured automobiles caused substantially more than their proportionate share of accidents, id. 'at 32-33.

"Settlementit' amourits' have little equity as between groups, injuries, and circumstances, varying 'most with litigation." Id. at :90. While extent of liability' and amount of expenses influence the amounts paid in settlements, these "show more variation, in terms of 'amount;' with' other personal factors, especially community status and business position. The most important variable, however, is the retention of an attorney by the claimant." Id. at 87. "The attitudes of insurers calling for' "buying' claims for as little as possible and the deteriorations of the application of the strict legal principles of liability to settling such cases has given rise to [the fact that the retention of an attorney substantially improves the chance of collecting as well as thie amount paid in settlement] . . Id. at 91 .

A study of the economic consequences of automobile accidents in New Haven, Connecticut during 1948 and 1949 is reported in James \& Law, Compensation for Auto Accident Victims: A Story of Too Little and Too Late, 26 CoNN. B.J. 70 (1952). 
compensation continue to claim that payments made under proposed plans would far exceed those made at present. ${ }^{28}$ If that is true, it is the very best evidence of the present system's inadequacy. Everyone knows the modest schedules of payments under compensation acts. Everyone knows too of the very large verdicts awarded in some cases under the present system, verdicts many times the maximum awards under any compensation scheme. If, in spite of these high awards, the total amount paid for claims today is far lower than it would be under a compensation system, then the amount paid on most claims must indeed be very far below that which would be paid under compensation-and even compensation would restore only a fraction of the actual economic loss. Pending further studies, then, it is reasonable to assume that the over-all inadequacy, the inequity, and the delays of the common law system are still with us.

A compensation system which would assure to all persons injured by motor accidents substantial and expeditious compensation for their economic loss and which would provide periodic payments for future needs would go far to cure these defects. The question, then, becomes whether an attempt to provide such a system would bring about even greater evils. This broad question has many facets and calls for an evaluation of some of the objections raised against the proposal. In making this evaluation it is important always to distinguish between the characteristics which such a scheme must have in order to eliminate the evils aimed at and other characteristics which any given proposal may have but which are not indispensable for the main purpose.

At the threshold is an objection which divides men philosophically. Some oppose compensation because it provides for liability without fault and for recovery even by one who has himself been negligent. They argue that those who want protection against injuries resulting from their own fault or from nobody's fault should insure, and that the innocent should not be

The studies conducted in Philadelphia and New Haven are briefly described in Marx, "Motorism," Not "Pedestrianism": Compensation for Automobile's Victims, 42 A.B.A.J. 421, 423-24 (1956).

One of the foremost students of the problem has recently concluded that "as a means of giving adequate protection against the machines of the highway, negligence law has run its course. Something better must be found." GREEN, TRAFFIC VICTIMS-TORT LAw AND INSURANCE 82 (1958). See also id. at 101.

28. This point was made by early opponents of compensation for automobile accidents. See Lilly, Criticism of the Proposed Solution, in Compensation for Automobile Accidents: A Symposium, 32 Colum. L. Rev. 785, 803 (1932); Sherman, Grounds for Opposing the Automobile Accident Compensation Plan, 3 LAW \& ConTeMr. ProB. 598 (1936). It is still stressed today. See McVay, Reply to "The Case for Compulsory Automobile Compensation Insurance," 15 Oнто ST. L.J. 161, 168, 169 (1954); Ryan \& Greene, Pedestrianism: A Strange Philosophy, 42 A.B.A.J. 117, 183 (1956). Mr. McVay, an insurance executive, "would estimate that the cost of Mr. Marx' plan . . would be two or three times that of the present day insurance policy, and perhaps closer to five or six times that cost." McVay, supra at 169. Mr. Marx' plan contemplated payments at the modest level of the Ohio Workmen's Compensation Act. See Marx, Compensation Insurance for Automobile Accident Victims: The Case for Compulsory Automobile Insurance, 15 Онхо ST. L.J. 134, 142-44 (1954). In spite of the implications of the strong statement just quoted, Mr. McVay finds the present system quite adequate. See McVay, supra at 162; McVay, The Case Against Compulsory Automobile Insurance, 15 Онго Sт. I.J. 150 (1954). 
compelled to care for them. ${ }^{29}$ This goes to the heart of the problem, for compensation proposals frankly reject ordinary negligence as the test, though they may take extreme fault into account. ${ }^{30}$ This rejection of negligence in turn rests on conclusions that fault-in the sense of clear ethical shortcoming -does not play a very significant part in present-day accidents, ${ }^{31}$ that modern industrial enterprises and activities like motoring will continue to take a more or less inevitable toll of life and limb, and that the accident loss should be reckoned as a cost of the activity which causes it and distributed broadly among those who benefit from the activity.

Opposition to the view just stated may come from a deep belief in laissez faire and in the kind of individualism that saw freedom of contract in the employment relationships of the early industrial revolution. Such an attitude would equally condemn workmen's compensation as socialistic-as indeed it did. Few would take so extreme a position today, ${ }^{32}$ but it cannot be said that the insurance principle should be applied to all accidents, or to all automobile accidents, simply because it is widely accepted for work injuries. The question is not so much whether the principle of social insurance is valid as where the line should be drawn in its application.

Proponents of automobile compensation point to workmen's compensation, which is widely conceded to be sound, ${ }^{33}$ as far as it goes, and to the similarities between the problems of automobile and industrial accidents. ${ }^{34}$ Opponents who are willing to accept compensation for work injuries seek to distinguish automobile accidents by arguing that in the latter there is no

29. See McVay, Reply to "The Case for Compulsory Automobile Compensation Insurance," 15 Oнго Sт. L.J. 162, 166-67 (1954); McVay, The Case Against Compulsory Automobile Insurance, 15 Oнто ST. L.J. 150, 152-53 (1954); Ryan \& Greene, supra note 28 , at 121 ; Sherman, supra note 28 , at $599-60$.

30. It may be taken into account as the basis of further liability in the case of extreme fault on the part of a person causing injury to another, or as the basis for reducing or barring compensation to a claimant.

31. See GreEN, op. cit. supra note 27, at 59-60; James \& Dickinson, Accident Proncness and Accident Law, 63 HARv. L. Rev. 769 (1950); Lewis, The Merits of the Automobile Accident Compensation Plan, 3 LAw \& CoNTEMP. PRoB. 583, 588 (1936); Marx, Compensation Insurance for Automobile Accident Victints: The Case for Compulsory Automobile Insurance, 15 Oнго ST. I.J. 134, 136-38 (1954); Netherton, Highway Safety Under Differing Types of Liability Legislation, 15 Oн10 ST. L.J. 110, 111-12 (1954).

32. Even Holmes, who in 1881 espoused the fault principle so completely, Hormes, The Common Law 96 (1881), thought in 1897 that the question of "how far it is desirable that the public should insure the safety of those whose work it uses," was "open to reconsideration," though he was not prepared to say how he "should decide if a reconsideration were proposed." Holmes, The Path of the Law, 10 HARv. L. REv. 457, 467 (1897).

33. Criticism is directed chiefly against limitations on and inadequacy of benefits under some state systems, the exclusiveness of the compensation remedy, and administrative features of the acts. See, e.g., Bear, Survey of the Legal Profession-Worlsmen's Compensation and the Lawyer, 51 ColuM. L. REv. 965 (1951); Conard, Workmen's Compensation: Is It More Efficient Than Employer's Liability?, 38 A.B.A.J. 1011 (1952); Horovitz, Editorial, 10 NACCA L.J. 17, 32 (1952).

34. Columbia Study 134-35; Saskatchewan Spectal Committee on the Problem of CoMpensation for Victias of AUtomobile ACCrDEnTs, Report 55-56 (1947) i Mara; "Motorism," Not "Pedestrianism": Compensation for Automobile's Victins, 42 A.B.A.J. 421, 426, 477-78 (1956). 
"sphere of endeavor" which causes the losses and no business enterprise through which the automobile owners can pass on their costs as can an employer. ${ }^{35}$ In automobile cases, they claim, the relationship between the parties does not warrant special treatment and does not assure the curbing of abuses. The automobile often injures a child or a housewife whose economic loss cannot be measured as can a worker's. ${ }^{36}$ And finally, they argue that there is no reason to single out automobile accidents when there are so many other sources of accidental injury, such as the home.

A comparison of the findings in the Columbia Study and the Railroad Study shows striking similarities in the economic consequences of accidents and in the inadequacy and inequality of compensation under common law systems in the fields of automobile accidents and work injuries. The social need for adequate and equitably distributed compensation is much the same; the differences do not seem weighty. Of course, automobile owners are not engaged in a joint venture for profit, but they do represent the class of people who benefit directly from motoring and who-like the ultimate consumers of the employer's products-may fairly be asked to contribute to the losses which their common activity of motoring causes. Thus there is a relationship between the parties sufficient to warrant strict liability, but it is a relationship that probably will not supply the same automatic check on malingering and other abuses as does the employment relationship. ${ }^{37}$ However, this does not mean that such abuses would be greater in automobile cases under compensation than they are at present. The problem of compensation for those not gainfully employed is not serious. ${ }^{38}$ And the objection to singling out the automobile approaches the trivial. The automobile accident has singled itself out, as its frequency and its economic consequences plainly show. It is perfectly true that automobile accident compensation is not a complete answer to all our woes. A good case can be made for a much broader type of social insurance, perhaps covering all disabilities from accident or illness. But those who raise the present objection would be the last to espouse anything like that. Their complaint is levelled against any extension of social insurance, and it is garbed in transparent hypocrisy when directed to the incompleteness of any proposed step.

I do not mean by this to belittle the resistance to steps which move away from individualism and laissez faire. We have witnessed a great resurgence

35. See Lilly, supra note 28 , at 805 ; Ryan \& Greene, supra note 28 , at 117 . For an admirable description and analysis of the similarities and dissimilarities, for this purpose, between industrial and automobile accidents, see Grad, supra note 15, at 325-27.

36. See Sherman, sipra note 28 , at 603 .

37. This objection was particularly stressed in Lilly, supra note 28.

38. Actual economic loss should be taken as the guide in all cases. While children and housewives may not carn wages, there may well be economic loss in terms of the need to hire a housekeeper and the like. Saskatchewan assigns an arbitrary amount to cover losses of this nature. Saskatchewan Spectar Committee on the Problem of Compensation for Victims of AutomobILe ACCIDENTS, REPORT 76 (1947). 
of this resistance as an emotional and political force since the war. This in itself may help to account for the failure of compensation to receive wider acceptance during that time, though it does not account for that failure during the years of depression and the New Deal. What I do mean is that this resistance is no longer an across-the-board intellectual attitude, except among a few visionary die-hards. ${ }^{39}$ Automobile compensation administered by private enterprise fits well within patterns now long familiar on the American scene.

Less extreme than an insistence on keeping the whole individualistic fabric of fault, and more widespread, is the feeling that no one should recover for an injury resulting from his own gross fault. The literature in opposition to compensation has many a reference to the drunken driver and even to the "drunken pedestrian running into the rear of a slowly moving car." 40 It may be that this reflects the prevailing attitude of people generally. If it does, then this should be reflected in a compensation scheme by providing that a claimant's gross fault will bar or diminish his award.

It may be noted in passing that loyalty to the fault principle may be inspired not only by a conservative philosophy but also by a desire to justify the very large award as one against the "wrongdoer." As may be expected, those who seek this justification are quite willing to see the requirement of fault diluted to the point where it no longer has any significant ethical content and is seldom a bar to liability. ${ }^{41}$

Some opponents see in compensation an invitation to carelessness, ${ }^{42}$ but such a fear is surely groundless. The stricter liability will if anything increase the incentive to exercise care, and insurance against liability will not engender irresponsibility under a compensation system any more than it does at present. ${ }^{43}$ There also is no more reason to suppose that individuals will be readier to risk injury for certain but modest awards than they are for the chance under the present system of the very large awards which are so widely publicized. Workmen's compensation was followed by a very material decrease in industrial accidents, ${ }^{44}$ and while automobile compensation

39. The theme that compensation would lead to state insurance and a narrowing of the field of private enterprise runs through most of the literature of the opposition. Sce articles cited note 28 supra. But the experience under workmen's compensation demonstrates that this is not necessarily so.

40. Ryan \& Greene, supra note 28, at 119; accord, Sherman, supra note 28, at 600 . While some opponents of compensation dramatize the possibility of such recoveries, many writers have minimized the importance of genuinely blameworthy conduct as a large factor in causing automobile accidents. See, e.g., James \& Dickinson, Accidcnt Proncness and Accident Law, 63 HARv. L. REv. 769 (1950); Netherton, supra note 31.

41. See Jaffe, Danages for Personal Injury: The Impact of Insurance, $18 \mathrm{LnW} \&$ Contenrp. Prob. 219, 230 (1953).

42. See Sherman, supra note 28 , at 600 .

43. What data there are show that accident records tend to be better where insurance is widely held. See 2 HARPER \& JAMES, TORTS $\$ 13.5$ (1956); James, Accidcnt Liability Reconsidered: The Impact of Liability Insurance, 57 YALE L.J. 549, 561-62 (1948). But see Netherton, supra note 31, at 121-22.

44. See 2 HARPER \& JAMES, TORTS \$ 13.5, at 775-76 (1956); Hall, Evcrybody's Job, 47 Best's Insurance News, March 1947, p. 85, at 96 (Fire \& Casualty cd.). 
may be less effective as a promoter of safety, there is no basis for thinking that it would increase accidents. ${ }^{45}$

The next set of objections to compensation deal with expense and adequacy. Spokesmen for defendants say that such a scheme would be intolerably expensive; those representing plaintiffs say that it would afford pitifully small awards. ${ }^{46}$ These contentions are interrelated and raise interesting and fundamental questions. So far as expense goes, that would depend on the amounts paid in compensation. It would be possible to devise schedules at such levels that the sum of compensation payments would not exceed the total amounts now paid for tort claims. The Railroad Retirement Board, for instance, found that railroads paid some 12 million dollars in claims and judgments under the FELA for injuries (including fatal injuries) incurred during selected months over a three-year period. It also found that the value of the past and estimated future wage loss resulting from these injuries was 24 million dollars. ${ }^{47}$ Actual payments varied from nothing to a great deal more than the actual wage loss in individual cases. The same money could have met about one-half of the wage loss in every case. ${ }^{48}$

The objection on the score of expense cannot stand alone. Whatever we can afford to pay could be distributed according to compensation, rather than common law, principles. The expense objection necessarily implies that the sum now spent on loss payments would not provide for adequate compensation.

Plaintiffs' men complain that a compensation system would yield only a pittance. To this several things should be said: (1) Under the present system the majority of persons get even less of a pittance, although a few get much more. (2) Periodic compensation for loss of future wages gives greater assurance that this loss will be replaced than does the same sum in lump payment. (3) However justifiable some large awards may be under the rules of liability and damages now in force (and many of them undoubtedly are), the great disparity in payments to those having similar economic losses cannot be justified; and the system which produces these disparities is inequitable. ${ }^{49}$

45. ". . . Saskatchewan highway safety officials state that compulsory compensation insurance has no effect upon highway safety ..." WIS. LEGrSLATIVE CoUNCr, op. cit. sipra note 15 , at 163 .

46. Typical defendants' views may be found in authorities cited note 28 supra. For plaintiff' 'views see Richter \& Forer, supra note 20; Tyack, No Heaven on Earth: Compensation for Automobile Victims, 44 A.B.A.J. 354 (1958).

47. RaIlroad Study 6. The total estimated wage loss was $\$ 30,500,000$. The figure given in the text represented an adjustment for the present value of future earnings. The cost to claimants of acquiring the $\$ 12,000,000$ was $\$ 1,000,000$.

48. This is something of an oversimplification. In death cases, for instance, the guide should be not wage loss, but probable contributions to dependents.

49. The notion that liability should be based on fault would of course justify some disparity in payments between persons having similar economic losses. But many factors besides fault enter into the disparities which actually exist today. Indeed fault is not 
Perhaps society can afford to pay more to its accident victims than it is now paying, and perhaps it should. This, of course, will always be a matter of debate and struggle. But however much or little society can afford or should be made to pay, the first claim against that sum should be in favor of meeting a substantial part of the serious economic loss ${ }^{50}$ of all accident victims. If anything remains, other considerations such as fault (with respect to liability) and pain and suffering (with respect to damages) may be considered in determining how the remainder should be distributed.

In this, it seems to me, lies the answer to the question whether the compensation remedy should be made exclusive. Saskatchewan does not make compensation exclusive, and the cost there of liability insurance is exceedingly rcasonable. ${ }^{51}$ Actuaries estimated that the cost of a similar scheme in North Dakota would be well within the bounds of reason. ${ }^{52}$ England no longer limits the worker's recovery for work injuries to compensation.63 Some continental countries provide for strict liability in automobile cases without limitation on the amount of recovery. ${ }^{54}$ In none of these jurisdictions, however, do the amounts awarded even remotely approach the sums awarded in the urban centers of this country for comparable injuries. Liability insurance rates here are already the highest in the world even though strict liability has not been adopted. Whether our unparalleled and unprecedented material prosperity would warrant putting our existing expensive system on top of a

even the principal determinant. Thus, the Railroad Retirement Board found a principal reason in the nonlegal "pressures and counterpressures that it is possible to exercise in the course of bargaining." RAILROAD STUDY 120. See also id. at 48. The study conducted in Philadelphia found that although liability and actual loss played a part, "there is rarely a clean-cut decision [on the basis of liability], but rather that it may be a matter of geographic location; who the persons involved are; circumstances of the insured and victim; the lawyer and doctor involved in the case and the like." Temple University Bureau of Economic and Business Research, supra note 27, at 73. See also $i d$. at 87,91 ; Corstvet, stipra note 6 , at $468-69$ (stressing the nonlegal bargaining pressures).

50. Since the serious personal injury and fatal cases cause the social problem, property damage claims might well be excluded from the system. See CoLUMinI Study 22-23. The Saskatchewan plan provides a $\$ 200$ deductible clatuse for property damaop liability. Saskatchewan Gov't Insurance OfFice, op. cit. stipra note 15 , at 18 . See also GREEN, op. cit. supra note 27, at 96.

51. The Saskatchewan compulsory policy protects the insured against liabilitv under the compensation plan and in addition against (1) liability under the common law up to a limit of $\$ 10,000$ for one person or $\$ 20,000$ for more than one person injured or killed in one accident, and $\$ 5,000$ for property damage in one accident (with $\$ \geqslant r_{0}$ deductible if the damage is caused in Saskatchewan); and (2) loss from collision, hail, theft, floot, wind, storm, and falling aircraft (with a $\$ 200$ deductible clause). The cost of this insurance is graduated according to the wheelbase and age of the car. In 1959 the premium for a 1956 Chevrolet was only $\$ 27.00$. SASKatchewan Gov't INSURANCE OFFICE, op. cit. stipra note 15 , at $4-8,35$.

52. Less than twice as much as Saskatchewan, if administered by state fund: between two and three times as much if administered by private insurers. N.D. LEGISLATIVE RESEARCH COMM.. op. cit. suthra note 15 . at 57 .

53. Lenhoff. Socia' In rurance Replacing Workmen's Compensation in England, 5 NACCA L.J. 49, 53 (1950).

54. See Malone, Damage Suits and the Contaoions Princible of Workmen's Compensation (pts. 1-2), 9 NACCA L.J. 20, 10 NACCA L.J. 44 (1952). 
compensation scheme may be open to some doubt, ${ }^{55}$ although a combined system would eliminate any duplication of benefits and might lead to a revitalization of the fault requirement.

Other objections are also related to this matter of expense. It has been argued that a compensation system is more expensive to administer (aside from any question of payments to claimants), and that it will invite more malingering and fraud than does the present system. If these charges are well founded they would constitute drawbacks to extending compensation.

The charge of expense is based on a study comparing the cost of administering workmen's compensation claims in Illinois with the cost of administering claims against Illinois railroads under the FELA. ${ }^{56}$ It was found that the latter system "costs less per dollar of benefit conferred." 57 The principal difference is in legal expense. ${ }^{58}$ While this is disappointingly high under compensation, the apparently good record under employers' liability may reflect an unhealthy state of affairs. The Railroad Retirement Board found that employees were generally afraid of being fired if they brought suit, or even retained lawyers to pursue their claims, against the railroad, ${ }^{59}$ which acts as a self-insurer in these cases. This means that much of FELA is being administered by the employers on a paternalistic basis and largely on their own terms. Self-insurance is rare under workmen's compensation, and the workmen's compensation board is generally accessible with an actively protective role to play. While the extent of litigation in workmen's compensation is deplorable, it must not be overlooked that much of it serves as a protection to the worker which is absent under the other system.

As to malingering and fraud, they thrive under the present system where rewards for success are occasionally dramatically high. ${ }^{60}$ There seems to be little reason to suppose that they will be increased by a system under which payments are limited. It is true that compensation would remove the need to fabricate facts to show liability, but the malingering problem is concerned with the extent of injuries and disability, and the present requirement of fault -diluted as it has become-affords no guaranty of trustworthiness in the testimony about injuries. Perhaps the delays and other difficulties of the

55. An Australian writer would reject any residual tort action because (1) it would siphon off money that should go towards financing compensation to pay "prizes for those who would play the common law action," and (2) the present system is primitive and clumsy as a deterrent against carelessness. Parsons, Death and Injury on the Roads, 3 U.W. Austr. AnN. L. Rev. 201, 273-74 (1955).

56. Conard \& MeHr, Costs of Admintstering Reparation for Work Injuries IN ILLINOIS (1952).

57. Conard, Workmen's Compensation: Is It More Efficient Than Employer's Liability?, 38 A.B.A.J. 1011, 1058 (1952). This article summarizes the findings of Costs of Administering Reparation for Work Injuries in Illinois.

58. CoNARD \& MEAR, op. cit. supra note 56, at 30, 42; Conard, supra note 57, at 1014.

59. RaIlroad Study 37-38; accord, Pollack, supra note 6, at 240. 491 (1936). 
present system discourage some false claims, but we know that they also discourage many meritorious ones and weaken the bargaining position of honest claimants. It is a harsh thing to deny or discourage meritorious claims for fear of opening the floodgates to litigation and fraud. The law has often done so for a time, but when the rule has finally been liberalized to accommodate merit, the flood has seidom come.

It is also true that continuing periodic payments present their own problems as a source of malingering and of protracting disability in more subtle psychological ways that do not involve conscious dishonesty. But techniques for combatting these problems exist, ${ }^{01}$ and at any rate the difficulties seem less serious than those of a system rigidly tied to the lump sum payment.

Some opponents of change--largely from among the ranks of plaintiffs' lawyers-see in a compensation scheme a threat to the institution of the jury trial. ${ }^{62}$ A fair appraisal of this objection requires careful analysis.

In the first place, the objection would have little weight with those who find the jury trial wanting. However, many Americans, including the present writer, believe the jury trial to be of value in accident cases. ${ }^{03}$ We must therefore proceed further with our analysis.

A belief in the jury system does not mean a belief that juries are being given the right issues to try or the right guides by which to try them. Juries played a valuable role in administering the law of seditious libel in sixteenth, seventeenth, and eighteenth century England, but that does not mean that the law of seditious libel was good. History has condemned that law, yet on the whole praised the role of the jury under it.o4. Indeed, a great strength of the jury is its ability to inject common sense, or contemporary popular prejudice, into the administration of an archaic or a harsh or an unwise rule of law. But surely that is no reason for keeping the rule. A belief in the jury system has no logical tendency to justify either the present rules of liability or the present rules of damages in accident cases. It would be entirely feasible to have the disputed issues of fact which would arise under a compensation system tried by juries. ${ }^{05}$

It is true that most existing workmen's compensation schemes have no provision for jury trial. Two overlapping reasons have contributed to this fact. Those who framed the American acts thought them so simple to

61. See Shulman \& James, Cases on Torts 454-55 (2d ed. 1952).

62. Lambert, Editorial, 17 NACCA L.J. 23 (1956); McKenzie, What is Truth? $A$ Defense of the Jury System, 44 A.B.A.J. 51 (1958); cf. Baer, supra note 33, at 974; De Parcq \& Wright, Damages Under the F.E.L.A., 17 Oнго ST. L.J. 430 (1956); Lambert, Editorial, 19 NACCA I.J. 25, 31 (1957).

63. See, e.g., 2 HARPER \& JAMIES, TORTS $\$ \$ 16.10,18.8$ (1956); Cooperrider, A Comment on The Law of Torts, 56 MICH. L. REv. 1291, 1299-1301 (1958).

64. See Chafee, Free Speech in the United States 497-517 (1941); 13 ENCYc. Soc. Scr. 636 (1934).

65 . In a few states the role of the jury is preserved under workmen's compensation. See HoROvitz, INJURY aNd DEATH UNDER WORKMEN'S COMPENSATION LAWS 291 (1944); Baer, supra note 33, at 974-75. 
administer that they would present few seriously litigated issues and therefore little need for juries. ${ }^{66}$ The legislatures also felt that the delays and expense incident to full judicial trials-and especially to jury trials-were among the evils of the older system to be avoided under the new one.67 Some may have had a third reason: perhaps they expected that administrators'would become expert in problems of work injuries and could solve these problems better than a lay jury. ${ }^{68}$

These reasons are all debatable. Experience has shown that workmen's compensation has given rise to much litigation teeming with the kinds of questions that could appropriately be left to a jury. ${ }^{69}$ Doubt has been cast on the relative efficiency and inexpensiveness of workmen's compensation administration. And there will always be disagreement as to whether an expert or a lay tribunal will solve questions of injury or disability in a way more satisfactory to society.

If any jurisdiction reaches the point of adopting a compensation scheme, it will have to decide whether to employ the jury trial. But this problem is severable from the threshold question: what should be the bases of liability and of damages?

Some opponents of compensation for automobile accidents stress the shortcomings of workmen's compensation. ${ }^{70}$ The chief complaint is the inadequacy of payments under existing state laws. The matter of over-all adequacy has already been treated. The present article is a plea neither for greater nor for smaller payments, but rather for a more equitable distribution of whatever we do pay. Some of these complaints, however, are directed against faulty methods of distribution within particular compensation systems. These features need not and should not be carried over to other systems. Thus, arbitrary maximum limits on the number of payments or on sums payable for medical expenses tend to discriminate against cases where the need is greatest. If penury must be practiced, let it fall rather on cases where need and hardship are least, by reducing or even eliminating payments on small claims. Again, a failure to adjust continuing payments to meet changes in

66. See id. at 968; Horovitz, Editorial, 10 NACCA I.J. 17, 28 (1952).

67. See Bohlen, A Problem in the Drafting of Workmen's Compensation Acts, 25 HARv. L. Rev. 328, 330-32 (1912).

68. Cf. Frank, Courts on TRLaL $108-46$ (1949); GREEN, op. cit. siupra note 27, at 97.

69. Some of them involve resolution of conflicts in the testimony. Examples are questions about the fact of injury and whether, if it happened at all, it happened on the job, the extent of injury or disability, and the fact and extent of dependency in fatal cases. Other questions quite appropriate for the jury's function involve an evaluation of legal consequences within limits set by law. Thus the phrases "arising out of and in the course of employment" or "of the use or operation of a motor vehicle" present many doubtful and close questions (even where facts are admitted) which could be resolved by a jury just as well as are questions regarding "scope of employment" in vicarious liability cases today. See 2 HARPER \& JAMES, TORTS \$26.8 (1956).

70. See Tyack, supra note 46; cf. GREEN, op. cit. supra note 27 , at $98-99$; Baer, sipra note 33; Horovitz, Editorial, 10 NACCA L.J. 17. (1952); RICHTER \& FoRER, supra note 20 . 
the cost of living is a defect in all existing compensation schemes which should be repaired in spite of the difficulties such adjustment would entail.

Other complaints are directed at the administrative side of compensation. In work injuries, it has led to a disappointing amount of litigation. Much of this turns on the deceptively simple phrase: "injury by accident arising out of and in the course of employment."71 It must not be forgotten that most of this litigation represents a constant extension of the borderlines of compensation. $^{72}$ Most of the cases litigated on this score would not have raised a question of the employers' liability at common law. Virtually this whole field represents pure gain from the point of view of those who would extend compensation, although the gain may have cost more in terms of friction than had been hoped. The other great sources of compensation litigation are questions regarding the extent of injury and disability. It may be assumed that a certain amount of this is inseparable from any adversary system wherein there is some effort by society to control the bargaining process. Litigation is a cost of this effort, and is probably worthwhile to curb the current evils of the bargaining. ${ }^{73}$

Workmen's compensation has its drawbacks, more in some state systems than in others. Automobile compensation would also have drawbacks, though it need not borrow all of those to be found in the weakest existing industrial accident systems. No one with any objectivity claims that the proposal would be a "heaven on earth." 74 But its detractors, I think, miss the woods for the trees. All compensation systems proceed on a basically more equitable principle of distributing payments for accident losses than does the common law. All of them provide for continuing payments to meet future needs, and most of them yield much prompter payments.

Why, then, has compensation failed of adoption in the automobile field while it has been adopted so widely in the field of industrial accidents? Those who do not like compensation will say that it is because most people disagree with my conclusion that it is desirable. I think this may be partly true but I doubt that most people have thought the problem through. The strongest force in the picture is, I suspect, the force of inertia. For generations we have thought of the civil recovery as coming out of a defendant's own pocket, and we have felt that it was unfair to impose this individualized liability unless the defendant was at fault. Yet this way of thinking no longer dominates the stage entirely. One of our most perceptive trial judges has said that "the

71. Baer, supra note 33, at 968; cf. Cardillo v. Liberty Mut. Ins. Co., 330 U.S. 469, 479 (1947).

72. See, e.g., Small, The Effect of Workmen's Compensation Tronds on AgcicyTort Concepts of Scope of Employment, 12 NACCA L.J. 21, 48-53 (1953).

73. What happens where the process of bargaining goes unchecked is the principal subject of the Railroad Study.

74. Opponents of compensation, however, sometimes suggest that its proponents make such a claim. Tyack, supra note 46. 
community no longer accepts as completely valid legal principles basing liability on fault."'75 Sixty years ago Holmes wrote that "the inclination of a very large part of the community is to make certain classes of society insure the safety of those with whom they deal."? We know about automobile liability insurance, and we are affected by the "contagious principle of workmen's compensation."77 And when as jurors we are called on to play an actual part in the working of the system, these factors have a very great influence on us-we tend to make the present system work in the actually litigated eases something like the way compensation would. Today's judges do something of the same thing when they liberalize tort rules and enlarge the jury's sphere. This in turn probably has some tendency to stifle the dissatisfaction we might have with the present system if we saw its workings in the large. ${ }^{78}$ Moreover, there is nothing to publicize and dramatize its hardships. They fall on scattered individuals, quietly. ${ }^{79}$ The human tragedy indicated by the dry statistics of the Columbia Study and the Railroad Study escapes the popular mind. No political pressure group is interested in playing it up; and there are many vested interests in the status quo. Publicity and drama exist, but only for the spectacular verdict or settlement. This makes the present system appeal to the gambling spirit so strong in American culture. Probably the large verdict and the recent liberalization of the legal climate have done more than anything else to win over most of the organized labor movement from their original espousal of workmen's compensation ${ }^{80}$ to their resistance to its present extension into the railroad field. ${ }^{81}$ And there is great and highly motivated opposition to compensation from the ranks of plaintiffs' lawyers for the same reasons. ${ }^{82}$ Ironically enough, these same factors may

75. Wyzanski, A Trial Judge's Freedom and Responsibility, 65 HARv. L. Rev. 1281, 1285 (1952).

76. Holmes, The Path of the Law, 10 HaRv. L. REv. 457, 466 (1897).

77. Malone, Damage Suits and the Contagious Principle of Workmen's Compensation, 9 NACCA L.J. 20 (1952).

78. This raises the question whether one should applaud or deplore common law developments which ameliorate the harshness of the present system. It has always seemed to me that steps in what $I$ think is the right direction should be welcomed for the benefits they confer directly and that it is pretty speculative how much such steps will retard the eventual accomplishment of more thoroughgoing reform. At any rate, the question is academic. Any system we have zoill change and will respond to pressures and social need whether or not we want it to do so; and while specific changes may be checked or impeded, they will not be avoided by frank appeals to keep the present system bad in order to hasten its end. Those who would work against reforms within the common law framework for this reason are, therefore, driven either to futility or to disingenuous tactics. See 2 HARPER \& JAMES, Torts $\$ 19.4 \mathrm{n.5}$ (1956); cf. Wyzanski, supra note 76 , at $1284-88$.

79. See Corstvet, supra note 6 , at 473. 7 (1944).

80. See Horovitz, Injury and Death Under Workmen's Compensation Laws

81. The resistance is not unanimous, but it is enough to deprive the movement of effective labor support. See Pollack, supra note 6 , at 261 n.77. The typical attitude of counsel for railroad unions and plaintiffs may be seen in Richter \& Forer, supra note 20.

82. The debates about compensation have been no more free from ad hominem arguments than human disputes usually are. Each side points out the selfish interests that motivate the other and charges his adversary with insincerity. Both sides try to 
ultimately build up counter-pressure, in favor of compensation, from insurance companies and the premium-paying public. ${ }^{83}$

The final question is whether we would be better served in the long run by a process of common law development toward strict liability than by a compensation scheme. Such a process is taking place now, and both courts and juries are playing a part in it. It has gone far and will no doubt go further in improving the actual operation of the rules of liability in litigated cases. But this is not enough. There is good reason to believe that the bulk of automobile victims fare no better today than they did at the time of the Columbia Study. Moreover, the underlying inequities among payments remain. Unless it can be shown that common law development ean produce a prompt, widespread, and, above all, equitable distribution of payments in accident cases, it should be replaced by a statutory scheme of compensation for automobile accidents. ${ }^{84}$

dismiss disinterested argument as coming from the proverbial "ivory tower." Such attacks may be effective as polemics, but they are out of place in an objective consideration. The high degree of motivation on the part of the plantiffs' lawyers is mentioned here not as tending to detract from the arguments they advance, but rather as one of the factors in the situation which tends to explain the nonadoption of compensation as a matter of power politics.

83. The study conducted in Philadelphia found: "Some company and some attorney" attitudes favor the development of a compensation coverage to help meet the present liability situation. However, half of the companies surveyed opposed it on philosophical or technical grounds and most of the attorneys opposed it as an invasion of individual rights." Temple University Burcau of Economic and Business Research, sitpra note 27 , at 91 .

84. Of course the liability to pay compensation would have to be secured by compulsory insurance or other proof of financial responsibility.

Two of the most provocative and forward-looking writers in the field of torts have proposed systems of loss insurance, rather than liability insurance, for motor accidents. EHRENZWEIG, "FULL AID" INSURANCE FOR THE TRAFFic VictiM (1954); GREen, op. cit. supra note 27 , at $87-92$.

Where traditional criteria of tort liability are retained, the difference between loss insurance and liability insurance is substantial. It is illustrated by the difference between the medical payments provision and the liability provisions of the modern automobile policy. The former is basically an undertaking to pay "to or for" a specified class of beneficiaries certain of the expenses caused by accidents involving the insured automobile. It is a form of accident insurance carried by the owner for the direct benefit of himself and others without regard to legal liability. The liability provisions are undertakings to pay on behalf of the persons insured "all sums [within policy limits] which the insured shall become legally obligated to pay as damages" for injury to person or property caused by operation of the automobile. The insurer's obligation to pay is thus conditioned on the ability to show the insured driver's tortious conduct.

Where the liability of the insured becomes absolute, as under a compensation scheme, the difference between loss insurance and property insurance becomes less significant, although it may have procedural and administrative consequences.

The present article is not concerned with a choice between the relative procedural and administrative advantages of these different forms of insurance. Either may have the features here suggested as vital. In my opinion, however, Professor Ehrenzweig's specific proposal lacks the needed force of compulsion, see James, Book Review, 43 CALrF. L. Rev. 559 (1955), while Dcan Green's fails to provide for continuing payments to meet future needs and may call for greater expenditures than we are willing to make.

In Professor Cooperrider's excellent critical comment on Harpcr \& James, The Law of Torts, he notes that my co-author and I "have neither a legislative program nor a systematic accident jurisprudence of [our] ... own to promote." Cooperrider, supra note 63, at 1299. For my own part, I have long favored a complete legislative revision of at least automobile accident law along the lines charted out by the Columbia Study, but we did not feel that a treatise on the law of torts was an appropriate vehicle for the promotion of such a legislative program (although we believe that we made our position clcar enough to meet fully the requirements of good faith). 